\title{
アメロゲニン遺伝子の多型性を指標としたウマの体細胞 および生殖細胞の性別判定法
}

\author{
福島康敏 ${ }^{a} \cdot$ 向山明孝 $^{1} \cdot$ 佐藤文大 $^{1} \cdot \mathrm{E}_{\mathbf{1}}$ 谷川晃久 $^{1}$ \\ 石田信繁 \\ 杤木県警察本部科学捜查研究所, 宇都宮市 320-8510 \\ 1 JRA 競走馬総合研究所, 宇都宮市 320-0856 \\ 2 宇都宮大学農学部, 宇都宮市 321-0943
}

(1998,11,12 受付, 1998, 12.17 受理)

\begin{abstract}
要 約 ウマ胎児（羟）の歯根部組織を材料としてcDNAライブラリーを調製し，ウマのアメロゲニ ン遺伝子の塩基配列とアミノ酸配列の構造解析を行ったところ，ウマのX染色体上のアメロゲニン遗 伝子 cDNAの第 1 から第 6 エクンンまでのアミノ酸残基怙よび非翻訳領域を含む $696 \mathrm{bp}$ を解読し，Y 染色体では第 5 エクン領域内の 24 bp が欠損していることを見い出した，そこで，このY染色体の久 損部位を含む第 5 エクソン領域内の部分配列を堌幅するためのプライマーを合成し，PCR 増幅した産 物をアガロースゲル電気泳動により分離したところ，雌雄間で分子サイズによる差巽が認められた。こ の塩基配列差異による多型性を指標として, ウマの 14 品種個体, 性染色体異常馬および培養細胞につい て性別判定法を行ったところ，いずれる正確な性別を判定することができた，さらに，本法によってウ マの各精子についての X または Y 精子確認を行うことができた.
\end{abstract}

日本畜産学会報, $70(7): J 6-J 10,1999$

ヒトや動物の菌のエナメル質の形成に関与するアメロ ゲニン（amelogenin）遺伝子は，XおよびY染色体上に

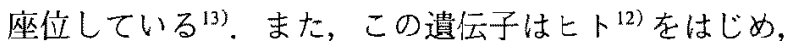
ウシ15)，ヒッジおよびャギ8などの一部の動物において は，エクソン領域ないしイントロン領域の塩基配列に多 型性が認められており，この多型は体外授精や胚移植な どにおける性別判定用 DNA マーカーとして利用され始 めている1-3,11).

本研究ではまず, ウマのアメロゲニン遺伝子の塩基配 列とアミ，酸配列の構造解析を行い，X $\mathrm{X}$ およ゙ $\mathrm{Y}$ 染色 体間に怙ける塩基配列の差異（多型性）を検索し，次に この多型性（性差）を指標としたウマの性染色体異常個 体, 培養細胞や精子に対する雌雄ないしX，Y判別法と しての利用性について検討したので報告する。

\section{材料および方法}

ウマの供試組織，血液および精液

ウマ萪根部組織は, 臨木繁殖実験において剖検したウ
マ胎児 (6力月齢雌および 3 力月齢雄) より採取したも のを使用した。また，供試血液は，サラブレッドなどの 軽種 4 品種, シャイヤーなどの重種 3 品種, ポニーおよ びミニチュアホースなど 4 品種ならびに木尊馬などの日 本在来馬 3 品種合計 14 品種を用いた。 また，性染色体異 常馬の血液はXY female 2 例より採血したものを用い た。さらに，ウマの培養細胞は腎皮質細胞，皮䖉上皮細 胞ならびにメラノーマ由来の継代培養細胞を用いた。 ま た，ウマ精液はサラブレッド種雄ウマより横取り法に よって採取したすのを用いた。

なお，ウマ柬根部組織からは，チオシアン酸グアニジ ン/塩化セシウム添加超遠心法により，全 RNA 画分を 抽出し, Oligotex dT30 super を用いて 3 端に poly-A 鎖 を付加した mRNAを分離した，また，細胞，血液および 精液加らは，プロティネース Kによる蛋白分解法およ び常法のフェノール・クロロホルム・エタノール沈澱法 によってゲノムDNAを抽出・精製した。

${ }^{2} J$ RA 競走馬総合研究所研究生

連絡者 : 福島康敏（fax：028-623-3815）

Anim. Sci. J. 70 (7) : J6-J10, 1999 


\section{ウマのアメロゲニン遺伝子の塩基配列解読}

既知のヒトおよびゥシのアメロゲニン遺伝子の第 $5 エ$ クソン領域の一部配列をもとにして合成したプライマー によって, ウマのゲノム DNA をPCR 増幅し，塩基配列 解読した PCR 増幅産物をプローブとして, ウマ胎児： 雌 (XX) および雄 $(\mathrm{XY})$ の下顎菌根部組織より RT-PCR 法によって調製したcDNAライブラリーにつ いて，第 1 次扰よび第 2 次スクリーニングを行い，多数 の陽性クローンを得ることができだ）。これらのcDNA 陽性クローンならびに3’および5'RACE法によって伸 長したcDNA 増幅産物は, Dye Terminator 法によって シークエンス反応を行ったのち, Auto-DNA sequencer (ABI PRISM 377 ; PE Applied Biosystems) を用いて塩 基配列解読を行った。

\section{アメロゲニン遺伝子の多型性解析}

解読されたウマのアメロゲニン遭伝子cDNAの塩基 配列のうち, 第 5 エクンン領域内で多型性を示す部位を 増幅するために, オリゴヌクレオチドプライマー(AMESC-1:5'CCAACCCAACACCACCA GCCAAACCTCCCT 3', AMESC-2 : 3'AGCATAGGGGGCAAGGGCTGCAAGGGGAAT 5') を合成したのち, PCR 反忍液 (総量 $50 \mu \mathrm{l}$ ) として template $20 \mathrm{ng}$, primer $30 \mathrm{pmol}$, Premix Taq (宝酒造) $25 \mu l$, 隇菌蒸留水で $50 \mu l$ を調製し た. PCR 増幅条件は予備加熱 $94^{\circ} \mathrm{C} 5$ 分間行った後, シャ トル PCR 法にて加熱サイクル $\left(94^{\circ} \mathrm{C} 1\right.$ 分間, $68^{\circ} \mathrm{C} 1$ 分 30 秒) を 35 回行い，追加伸張を $72{ }^{*} \mathrm{C} 7$ 分間行った。こ のPCR 增幅産物は 4\%アガロースゲル（SeaKem GTG， FMC 社）を用いて，100V, 45 分間泳動し，エチジゥム・ ブロマイド染色した後，紫外線照射下で泳動像を観察 し，分子サイズによる雌雄間の差異（多型性）を確認し た.

\section{ウマ X および $\mathbf{Y}$ 精子の判定法}

Pinpoint Slide DNA Isolation System(フナコシ製品) を用いて，希䣋ウマ精液を塗布したスライド標本から フィルム状に固相された精子 1 個を取り出し, TNE+ DTT 緩衙液 (0.01M Tris- $\mathrm{HCl} \mathrm{pH} 8.0,0.01 \mathrm{M}$ EDTA, 0.1 $\mathrm{M} \mathrm{NaCl}, 0.04 \mathrm{M} \mathrm{DTT}$, 最終濃度 $1 \%$ SDS, 最終濃度 $100 \mu \mathrm{g} / \mathrm{ml}$ のプロティネース K) 抢よび常法のフェノー ル・クロロホルム・エタノール沈殿法によってDNAを 抽出した.この精子抽出 DNA を前述のPCR 反応条件 によって增幅反応を行い，得られた PCR 増幅産物につ いて 4\%アガロースゲル電気泳動を行い，エチジウム． ブロマイド染色した後, 紫外線照射下でXおよびY染 色体特異サイズバンドを観察した。

Anim. Sci. J. 70 (7) : J6-J10, 1999

\section{結果および考察}

ウマ胎児の下顎菌根部組織より調製した cDNAの塩 基配列解読を行ったところ, 図 1 に示す上うに，X染色 体上のアメロゲニン遺伝子cDNA の第 1 加第 6 エク ソンまでの 192 アミ/酸残基㧍よび非翻訳領域を含む $696 \mathrm{bp}$ の全程基配列を解読することができた，また $\mathrm{Y}$ 染 色体ではこの cDNA の第 5 エタンン領域内の $382 \mathrm{bp}$ ら 405 bp 間の 24 bp が久損していた。 ウマのアメロゲニ ン遺伝子の cDNA の構造的特徴と既知の七卜およびウ シの配列との相同性を調べるため，解読した塩基配列に ついて，遗伝子解析用プログラムソフトを用いてアライ メント解析を行ったところ，第 1 から第 4 エクンン部位

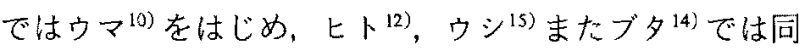
義的塩基置換が一部認められるものの ${ }^{7)}$, 極めて相同性 が高いものであった。

なお，これまでにアメロゲニン遗伝子の第 5 エクンン 領域内において，雌雄間の差異が認められる例としては ウシ (5)，ヒッジおよびヤギタが報告されているが，七卜 の場合は主にY染色体の第 3イントロン領域内に攵損 部位が䜑めれている(2).

このウマY染色体の欠損部位を含む第 5 エクンン領 域の部分配列（図 1）を增幅するためのプライマーを合 成し，雄㧍よび䊒の CDNA およびゲノムDNAをテンプ レートとして PCR 增幅を行い，その増幅産物をアガ ロースゲル電気泳動法 (PCR-AFLP) により分離確認し たところ，比 (XX) のCDNAおよびゲノムDNAのいず れもX染色体由来の $184 \mathrm{bp}$ の 1 本のバンドのみが検出 され，また雄 $(\mathrm{XY})$ では X染色体由来の $184 \mathrm{bp}$ と $\mathrm{Y}$ 染 色体由来の $160 \mathrm{bp}$ なびに過剩バンド 1 本（約 $200 \mathrm{bp}$ 付近）の合計 3 本のバンドが検出され，分子サイズによ る雌雄間の差異を確認することができた（図 2)。なお， Y 染色体走有する雄馬のPCR 增幅産物の電気泳動像で は過剩バンドが検出されるが，この現象については， Ganguly ら"行にるとテンプレートDNAの二重ラセン に不整弯曲や構造的变化が生ずると，PCR 增幅の際に 不適切な接合組み合わせが出現し，ゲル電気泳動に扔い てへテロ二重鎖の特異的な過剩バンドが出現すると報告 している，そこで，X，Y染色体の 24 bp の美異によって 生ずる不整接合弯曲などがこの過剩バンドの生成に関与 していることを間接的に証明するため，雄および倠の

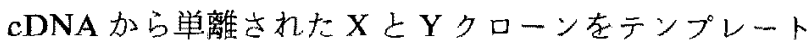
として PCR 增幅産物を調製し，アガロースゲル電気泳

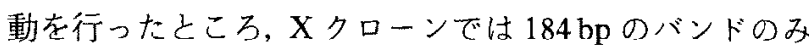
がまた Yのクローンにおいては 160 bp のバンドのみ 


$$
\text { 福島・向山・佐藤・長谷川・石田・村松 }
$$

5. GGATCAGGCATCCCTGAGTTICAGACAGAMCTTACTCGGMIACGTATATTCAMTGGGCCATCMAGM

ATG GGG ACC TGG ATT TTG TIT GCC AGC CTC CTG GGA GCA GCC TTT GCT ATG CCC Met Gly Thr Trp Ile Leu Phe ALa Ser Leu Leu Gly Ala Ala Phe ala Met Pro

CTA TAT CTC ATC CTG GGC ACC CTG GGT TAT ATC MAC TTC AGC TAT GAG GTG CTT 198 Leu Tyr Leu lle Leu Gly Jhr Leu Gly Tyr Ile Asn Phe Ser Tyr Glu Val Leu ACC CCT CTG AMG TGG TAC CAG AGC TIG ATC AGG CAG CCG TAC ACT TCC TAT GGT 162 Thr Pro Leu lys Trp Tyr Gin Ser Leu Ile Arg Gin Pro Tyr Thr Ser Tyr Gly

TAC GM CCC ATG GGT GGA TGG CTG CAC CAC CMA ATC ATC CCC GTG CTG TCC CAG 216 Tyr Glu Pro Met Gly Gly Trp Leu His His Gln Ile Ile Pro Val Leu Ser Gín

CAG AAT CCC TCA MAT CAC GCC ITG CAG CCT CAT CAC CAT ATC CCC ATG GTG TCG 270 Gin Asn Pro Ser Asn his Ala leu gln Pro His His His Ile Pro Met Val Ser GCT CAG CAC CCT GTG GTC CCC CAG CA CCA ATG ATG CCA CTT CCT GGC CAA CAC 324 Ala Gln His Pro Val Val Pro Gln Gln Pro Met Met Pro Leu Pro Gly Gln His Primer CCA ACC CAM CAC CAC CAG CCA AaC CIC CCT CCA CCT GTC CAG CAG 378 Ser Met Val Pro Thr Gln His His GIn Pro Asn Leu Pro Pro Pro Val Gin Gin CCC tte cac eec cag ect gte cag eeg CAG CCT CAC CAG CCC ATC CAG CCT CAG 432 Pro Phe His Pro Gln Pro Val GIn Pro Gln Pro His Gln Pro lie Glo Pro Gín

CCA CCI CIG CAC CCC ATC CAG CCC CTG CCG CCa CAG CCA CCT CTG CCT CCG ATA 486 Pro Pro Leu His Pro lle GIn Pro Leu Pro Pro Gln Pro Pro leu Pro Pro Ile

ITC CCC ITG CAG CCC TTG CCC CCT ATG CTI CCT GAC CTG CCT CTG GM GCT IGG 540 Plie Pro Leu Gln pro leu Pro Pro Met Leu Pro Asp Leu Pro Leu Glu Ala Irp

CCA GCA ACA GAC MAG ACC AAG CGG GAG GA GTG GAT TAA 579 Pro Alo Thr Asp Lys Thr Lys Arg Glu Glu Val Asp : *

MGGATCAGAMCTGAGAMGCAGATACTTCAGTTGCTTTCAGAATGACACAGGACACAMTGATTTGTGC CTATCATCACTTAGTAMATTCGTGACTAMATTAGTTACAATTACAMACOGTOGOTGGTTITTAMATT
CAA

Fig. 1. Nucleotide sequences and predicted amino acid sequences of equine amelogenin cDNA.

The deletion parts $(24 \mathrm{bp})$ in nucleotide sequences of equine $\mathrm{Y}$ chromosome were expressed with lowcases.

The arrows were shown sequence locations of oligonucleotide primers $\left(5^{\prime}\right.$ : AMESC-1, 3' : AMESC-2).

がそれぞれ確認された。また，X上Yクローンを混合し たすのをテンプレートとして PCR 增幅した産物では, 雄の cDNA 之同様に $\mathrm{Y}$ 染色体および $\mathrm{X}$ 染色体と少し遅 れて1本の計 3 本のバンドが出現した，したがって，こ れらの結果は, Ganguly ら゙)よる報告老裹付けるもの であった。

そこで，このアメロゲニン遗伝子の多型性による分子 サイズ差異を指標とした PCR-AFLP法を，ウマの性別 判定法として利用するため，軽種や重種，ポニ一，また 日本在来馬など 14 品種の子馬招よび成馬の雄, 雌およ び騙馬の血液について, 倠雄の鑑別を行ったところ,い
ずれあ正しい性別判定を行うことができた。

また，本法を性染色体異常馬における性染色体確認の ための検査法として利用できるか検討したところ，XY female馬 (2頍 $)^{9)}$ ではいずれ禾X染色体の 184 bp バン ドと $\mathrm{Y}$ 染色体の $160 \mathrm{bp}$ バンド, さらに 1 本の過剰バン ドの計 3 本のバンドを検出することができた（図2）。こ のXY female馬については，これまでに長谷川らうに よって単離された馬の性決定遗伝子（SRY）を指標とし たPCR-AFLP では，Y染色体の存在を示す 1 本のバン ドが出現されているが，本法を併用することによって， $\mathrm{X}$ 染色体の確認も行えるため，より正確な性染色体確認 


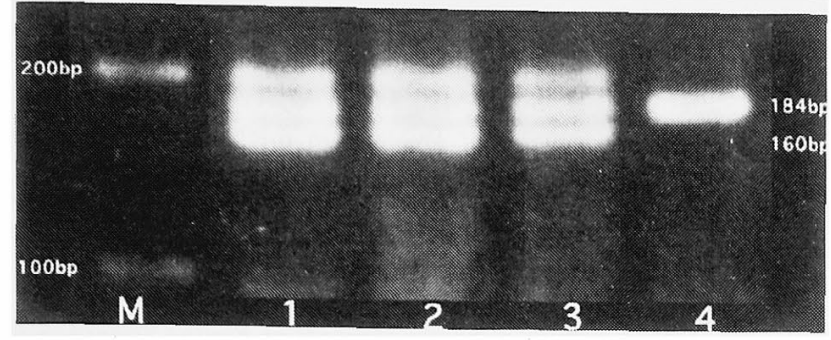

Fig. 2. Sex determination of equine blood samples by PCR-AFLP with Amelogenin primer.

M : BioMaker Low 3 : Thoroughbred (male)

1 : XY female 4 : Thoroughbred(female)

2 : Thoroughbred (gelding)

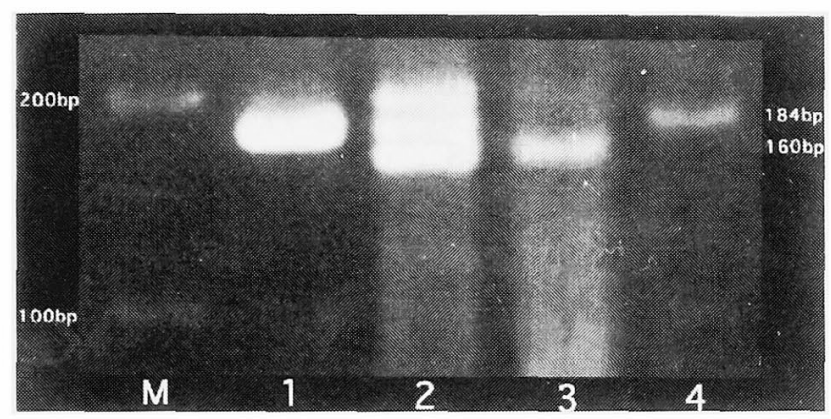

Fig. 3. Identification of $\mathrm{X}$ and $\mathrm{Y}$ sperm by PCR products with Amelogenin primer.

M : BioMaker Low 3 : Sperm (Y chromosome)

1 : Female genomic DNA 4 : Sperm (X chromosome)

2 : Male genomic DNA

が行えるあのと考えられる.

さらに, 本法をウマの各種の培養細胞 ${ }^{16)}$ が雌雄のいず れに由来するあのか, また継代培養を重ねることによっ て性染色体の欠落などの異常が認められるかの検査法と しての利用性について, 数代から 10 数代に渡って継代 したメラノーマ, 皮䖉, 腎および骨格筋由来の培養細胞 に対してXおよび $\mathrm{Y}$ 染色体の確認を行ったところ，い ずれす組織採取した原馬の性別に一致した性染色体バン ドが検出され，本法が培養細胞の性別判定にも利用でき ることが判った.

一方, 家畜の体外受精や胚移植などの生殖工学の発展

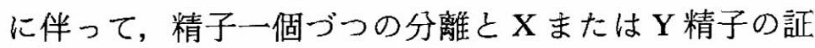
明検査が必要になってきており，すでにウシ等6)の一部 の家畜では精子染色体確認が確立されている，そこで， 本法がウマの各精子の $\mathrm{X}$ または $\mathrm{Y}$ 精子検查に利用でき るか確認実験を行ったところ, 図 3 に示すように，1個 の X 精子から $184 \mathrm{bp}$ バンドが，また 1 個の $\mathrm{Y}$ 精子から
$160 \mathrm{bp}$ バンドがそれぞれ観察され，確実に精子 1 個の性 染色体を確認することができた.

\section{謝辞}

本研究を行うにあたり, XY female 馬の血液試料を提 供していただいた岩手大学農学部三宅陽一教授およびへ ルシンキ大学 Makinen A. 教授に深謝します.

\section{文献}

1) Akane A, Shiono $H$, Matsubara $K$, Nakamura $H$, Hasegawa M, Kagawa M. Purification of forensic specimens for the polymerase chain reaction. Journal of Forensic Science, 38 : 691-701. 1993.

2) Cui $X$, Kudo $T$, Sutou $S$. Sexing of bovine embryos with male-specific repetitive DNA by polymerase chain reaction : Characterization and mapping of bovine malespecific and gender-neutral repetitive DNA. Journal of Reproduction and Development, 42 : 125-131. 1996.

3) Ennis S, Gallagher TF. A PCR-based sex-determination assay in cattle based on the bovine amelogenin locus. Animal Genetics, 25 : 425-427. 1994.

4) Ganguly A, Rock MJ, Prockop DJ. Conformation-sensitive gel electrophoresis for rapid detection of single-base differences in double-stranded PCR products and DNA fragments. Evidence for solventinduced bends in DNA heteroduplexes. Proceedings of The National Academy of Siences of The United States of America, 90 : 10325-10329. 1993.

5) Hasegawa $T$, Ishida $M$, Harigaya $T$, Sato $F$, Ishida $N$, Mukoyama H. Linear SRY transcript in equine testis. The Journal of Veterinary Medical Science, 1999. (In Press)

6) Howes EA, Miller NGA, Dolby C, Hutchings A, Butcher GW, Jones R. A search for sexspecific antigens on bovine spermatozoa using immunological and biochemical techniques to compare the protein profiles of $\mathrm{X}$ and $\mathrm{Y}$ chromosome-bearing sperm populations separated by fluorescence activated cellsorting. Journal of Reproduction Fertilty, 110 : 195-204. 1997.

7) $\mathrm{Hu} \mathrm{CC}$, Bartllet JD, Zhang $\mathrm{CH}$, Qian Q, Ryu OH, Simmer JP. Cloning, cDNA sequence, and alternative splicing of porcine amelogenin mRNAs. Journal of Dental Reserch, 75 : 1735-1741. 1996.

8) Liau DW, Shults C, Geisert RD, Rickords LF. Sequence homology of AMELX and AMELY gene in ovine and caprine sequence. Plant \& Animal VI, Poster Abstracts : 156. 1998.

9) Makinen A, Hasegawa T, Makila M, Katila T. Infertility in mares with XY and XXX sex chromosomes. Equine Veterinary Journal, 1999. ( In Press)

10）向山明孝 - 佐藤文夫 - 長谷川晃久 - 石田信繁 $\cdot$ 福島康 敏. ウマのアメロゲニン遺伝子の cDNA クローニング に上る塩基配列解読之多型性解析. DNA 多型, 6:106 109. 1998. 


\title{
福島・向山・佐藤・長谷川・石田・村松
}

11) Nakahori $Y$, Hamano $K$, Iwaya $M$, Nakagome $Y$. Sex Identification by polymerase chain reaction using $X-Y$ homologous primer. American Journal of Medical Genetics, 39 : 472-473. 1991 .

12) Nakahori $Y$, Takenaka $O$, Nakagome $Y$. A human $X-Y$ homologous region encords 'amelogenin'. Genomics, 9: 264-269.1991

13）清水信義. ヒト染色体の遺伝子マッピング、日本踟休， 47 : 20-58, 1989.

14) Shimokawa $H$, Ogawa $Y$, Sasaki $S$, Sobel ME, Mequillan CI, Termine JD, Young MF. Molecular cloning of bovine amelogenin cDNA. Advance in Dental Reserch, $1: 293-$ 297. 1987.

15) Shimokawa H, Sobel ME, Sasaki M, Termine JD, Young MF. Heterogeneity of amelogenin mRNA in the bovine tooth germ. The Journal Biological Chemistry, 262 : 40424047. 1987.

16) Watanabe $S$, Ishikawa $Y$, Hara $H$, Hanzawa $K$, Mukoyama H. A method of primary cell culture for establishing equine long-term culture cell lines. Journal of Equine Science, 8 : 95-99. 1997.

\section{Sex Determination of Equine Somatic and Germ Cells by PCR Amplification Based on the Sequence Polymorphism of $\mathrm{X}$ - and Y-Chromosomal Amelogenin Genes}

\author{
Yasutoshi FUKUSHIMA, Harutaka MUKOYAMA', Fumio SATO', Telhisa HASEGAWA ${ }^{1}$, \\ Nobushige ISHIDA ${ }^{1}$ and Susumu MURAMATSU ${ }^{2}$ \\ Forensic Science Laboratory, Tochigi Pref. Police Headquarters, Utsunomiya-shi 320-8510, Japan \\ 'Equine Research Institute, JRA, Utsunomiya-shi 320-0856, Japan \\ ${ }^{2}$ Department of Agriculture, Utsunomiya University, Utsunomiya-shi 321-0943, Japan \\ Corresponding : Yasutoshi FUKUSHIMA (fax : +81 (0) 28-623-3815)
}

Two distinct transcripts for equine $\mathrm{X}$ - and $\mathrm{Y}$-chromosomal amelogenin genes were cloned from male and female fetal ameloblast cDNA libraries. The complete nucleotide sequence of equine X-chromosomal amelogenin cDNA was 696 -base-pairs (bp) that encodes a protein with 192 amino acid residues. The deletion of $24 \mathrm{bp}$ was found in the fifth exon of equine Y-chromosomal amelogenin gene. The genomic DNAs of equine male and female were amplified by the polymerase chain reaction using a pair of nucleotide primers from an $X / Y$-homologous region of amelogenin gene. The PCR product from mare genomic DNA revealed a single band ( $184 \mathrm{bp}$ ) corresponding to the X-chromosome by $4 \%$ agar gel electrophoresis. And the PCR products from stallion and gelding genomic DNA showed three bands which were two distinct bands ( $184 \mathrm{bp}$ and $160 \mathrm{bp}$ ) with X-and Y-chromosome and an additional band ( $\sim 200 \mathrm{bp}$ ) of heteroduplex. This PCR polymorphism of X-and Y-chromosomal amelogenin genes enabled sex determination of single sperm as well as equine culture cells.

Animal Science Journal, 70 (7) : J6-J10

Key words : Sex determination, Equine amelogenin gene, Sequence polymorphism, PCR, Culture cells 